\title{
HIV/AIDS practice patterns, knowledge, and educational needs among Hispanic clinicians in Texas, USA, and Nuevo Leon, Mexico
}

\author{
J. Louis Martinez, ${ }^{1}$ Juan de Dios Licea Serrato, ${ }^{2}$ \\ Richard Jimenez, ${ }^{1}$ and Richard M. Grimes ${ }^{1}$
}

ABSTRACT Hispanic clinicians in Texas, United States of America, and in the neighboring state of Nuevo Leon, Mexico, were surveyed to determine their educational needs in the area of HIV/AIDS. Two-thirds of the 74 Texan and 22\% of the 104 Mexican physicians queried had seen at least one HIV/AIDS patient in the previous year. The majority of the respondents were primary care physicians who: 1) were in private practice; 2) saw more than 1000 patients per year; 3) had been out of training for more than 10 years; 4) provided some HIV prevention education to patients based on their perceived risk of infection; 5) rated their own knowledge of HIV/AIDS as average but rated their knowledge of treatments for the disease below average; 6) received most of their information about HIV/AIDS from journals rather than formal continuing education programs; 7) thought Hispanic patients had special needs with regard to HIV/AIDS care; and 8) were willing to attend education programs to improve their HIV/AIDS management skills. The greatest barriers to caring for HIV patients were lack of clinical knowledge and fear of infection. These results point to a need for a large-scale training program to improve the HIV/AIDS management skills of Hispanic clinicians in Texas and Nuevo Leon.

The United States of America and Mexico share a 3326-km border and, consequently, many public health problems, with AIDS being prominent among them. As of June 30, 1996, the

\footnotetext{
University of Texas-Houston Health Science Center, School of Public Health, Houston, Texas. All correspondence should be mailed to J. Louis Martinez at the following mailing address: AIDS Education and Training Centers, School of Public Health, University of Texas-Houston Health Science Center, RAS 345, P.O. Box 20186, Houston, Texas 77225-0186, USA.

2 Consejo Estatal del SIDA, Monterrey, Nuevo Leon, Mexico.
}

U.S. had reported a total of 548000 AIDS cases; by October of that same year, Mexico had reported 28776 , the third highest total of any country in the Western hemisphere $(1,2)$. Both countries report a significant number of cases along the shared border. The four border states of the U.S. have had 137097 cases and the six border states of Mexico, 3460 cases (1, and Luis Anaya, Registro Nacional de Casos de SIDA, personal communication, 15 January 1997). The U.S. border states saw a tripling of the number of cases from 1990 to 1996 , while cases in the
Mexican border states increased by nearly five-fold during the same years $(3,4)$. Among AIDS cases reported in the U.S., over $17 \%$ have been in Hispanic individuals (1). In Texas, a border state that had reported 37320 AIDS cases as of mid-1996, 17\% of patients have been Hispanics (5), and most of them probably had Mexican backgrounds. According to the 1990 census, nearly $90 \%$ of Texas Hispanics trace their ancestry to Mexico (6).

A previous study showed that Hispanics in Texas seek and receive much of their medical care from clinicians 
who are of Hispanic descent (7). Based on these findings, it is likely that Hispanics with human immunodeficiency virus (HIV) infection or AIDS would also prefer to receive care from Hispanic care providers. The present study was undertaken to ascertain the extent to which Hispanic caregivers along one stretch of the border provide care for patients with HIV/AIDS; the barriers to their providing such care; and their educational needs with respect to HIV/AIDS.

A survey was conducted among Hispanic clinicians in Texas, USA, and the Monterrey area of Nuevo Leon, Mexico. The survey elicited data on the respondents' 1) personal characteristics and medical practice, including HIV caseload and current practices with regard to HIV prevention and education; 2) self-assessed knowledge about HIV/AIDS and available treatments and sources of information about the problem; 3) willingness to provide care to HIV/AIDS patients and perceived barriers to providing such care; and 4) perception as to whether or not Hispanic patients have special needs with regard to HIV/AIDS.

\section{MATERIALS AND METHODS}

The study was inaugurated in Texas as part of continuing education training assessments carried out by the AIDS Education and Training Center (AETC) for Texas and Oklahoma. One of the authors (JLM) arranged interviews with Hispanic physicians of his acquaintance in the Houston area. These physicians were then asked to recommend Hispanic colleagues who might be willing to submit to an interview.

Forty clinicians were interviewed in their practice settings, using a standard questionnaire. Previous experience has shown that face-to-face interviews yield a much richer assessment of educational needs than mail surveys. The interviews were conducted primarily in English, but Spanish was used as cued by the respondent.

Because the AETC has responsibility for all of Texas, a mailing list of His- panic physicians in the state was obtained from the Inter-American College of Physicians and Surgeons. Ninety of these physicians were sent English language questionnaires. Thirty-four responded and were included in the study.

The Mexican portion of the study began with the Mexican co-author (JdDLS) interviewing physicians of his acquaintance who practiced in the Monterrey area of Nuevo Leon, where more than $85 \%$ of Nuevo Leon clinicians have their practice. These physi- cians provided leads to colleagues, some of whom participated in the study. All interviews were conducted in the physicians' normal practice settings, using a Spanish translation of the questionnaire applied in Texas. The questionnaire was modified slightly for the Mexican context.

All data were collected between December 1994 and April 1996. A preliminary analysis found no significant differences between the Houston area clinicians' responses and those of the Texas clinicians interviewed by mail.

TABLE 1. Personal and practice characteristics of respondents

\begin{tabular}{|c|c|c|c|}
\hline & $\begin{array}{l}\text { Texas } \\
\text { No. }(\%)\end{array}$ & $\begin{array}{c}\text { Nuevo Leon } \\
\text { No. (\%) }\end{array}$ & $\begin{array}{c}\text { Total } \\
\text { No. (\%) }\end{array}$ \\
\hline \multicolumn{4}{|l|}{ Age of respondents } \\
\hline $25-30$ & $4(05)$ & $4(04)$ & $8(04)$ \\
\hline $31-35$ & $11(15)$ & $10(10)$ & $21(12)$ \\
\hline $36-40$ & $19(26)$ & $29(28)$ & $48(27)$ \\
\hline $41+$ & $40(54)$ & $59(57)$ & $99(56)$ \\
\hline No response & 0 & $2(02)$ & $2(01)$ \\
\hline Total & 74 & 104 & 178 \\
\hline \multicolumn{4}{|c|}{ Years since last formal training } \\
\hline $1-3$ & $13(18)$ & $6(06)$ & $19(11)$ \\
\hline $4-6$ & $6(08)$ & $3(03)$ & $9(05)$ \\
\hline $7-10$ & $6(08)$ & $10(10)$ & $16(09)$ \\
\hline $11-15$ & $15(20)$ & $23(23)$ & $38(21)$ \\
\hline $15+$ & $24(32)$ & $60(59)$ & $84(48)$ \\
\hline No response & $10(14)$ & $2(02)$ & $12(07)$ \\
\hline Total & 74 & 104 & 178 \\
\hline \multicolumn{4}{|l|}{ Patients seen annually } \\
\hline $1-300$ & $5(07)$ & $0(00)$ & $5(03)$ \\
\hline $301-500$ & $3(04)$ & $0(00)$ & $3(02)$ \\
\hline $501-1000$ & $9(00)$ & $13(13)$ & $22(12)$ \\
\hline $1000+$ & $55(76)$ & $89(85)$ & $144(81)$ \\
\hline No response & $2(03)$ & $2(02)$ & $4(02)$ \\
\hline Total & 74 & 104 & 178 \\
\hline \multicolumn{4}{|l|}{ Specialty area } \\
\hline General/family practice & $31(42)$ & $46(45)$ & 77 (43) \\
\hline Internal medicine & $9(12)$ & $29(28)$ & $38(21)$ \\
\hline Dentistry & $4(05)$ & $3(03)$ & $7(04)$ \\
\hline Other & $30(41)$ & $26(25)$ & $56(32)$ \\
\hline Total & 74 & 104 & 178 \\
\hline \multicolumn{4}{|c|}{ Place of medical/dental school training } \\
\hline United States & $30(41)$ & $2(02)$ & $32(18)$ \\
\hline Mexico & $15(20)$ & $99(95)$ & $114(64)$ \\
\hline Other & $20(27)$ & $1(01)$ & $21(11)$ \\
\hline No Response & $9(12)$ & $2(02)$ & $11(06)$ \\
\hline Total & 74 & 104 & 178 \\
\hline \multicolumn{4}{|l|}{ Practice setting } \\
\hline Private practice & $41(55)$ & $76(73)$ & $117(66)$ \\
\hline Public clinic & $21(28)$ & $21(20)$ & $42(24)$ \\
\hline Hospital & $7(10)$ & $6(06)$ & $13(07)$ \\
\hline Other & $5(07)$ & $1(01)$ & $6(03)$ \\
\hline Total & 74 & 104 & 178 \\
\hline
\end{tabular}


Therefore, subsequent analyses considered two groups: clinicians from Texas and from Nuevo Leon.

\section{RESULTS}

\section{Characteristics of respondents and their medical practices}

Overall, the respondents were a mature, experienced group of active clinicians. As shown in Table 1, the majority were over 40 years of age. Fifty-two percent in Texas and $82 \%$ in Nuevo Leon had finished their last residency training more than 10 years before. Over $80 \%$ saw in excess of 1000 patients a year. Most were primary care physicians in either family or general practice or internal medicine $54 \%$ in Texas and $73 \%$ in Nuevo Leon). The remainder had a variety of specialties, including obstetrics and gynecology, oncology, dermatology, urology, dentistry, and surgery. Almost all physicians in Nuevo Leon (95\%) attended medical school in Mexico. Of physicians in Texas, around $40 \%$ received their primary clinical education in the U.S.; $20 \%$ trained in Mexico; and the remainder trained in a variety of countries. Most Texas respondents were in private practice $(55 \%)$ or worked in public clinics $(28 \%)$. The majority of physicians in Nuevo Leon reported being in private practice $(73 \%)$. As is usually the case in Mexico, many members of this group also held salaried positions in public clinics.

In summary, although survey respondents were not a random sample of physicians from the two states, they represent a diverse group of senior, clinically active physicians from a number of different backgrounds and specialties.

\section{Practice characteristics as related to HIV/AIDS}

As indicated in Table 2, 13\% of the physicians in Nuevo Leon and 67\% of the clinicians in Texas had knowingly seen an HIV-infected patient in the

TABLE 2. HIV/AIDS in the respondents' practices

\begin{tabular}{|c|c|c|c|}
\hline & $\begin{array}{l}\text { Texas } \\
\text { No. (\%) }\end{array}$ & $\begin{array}{l}\text { Nuevo Leon } \\
\text { No. (\%) }\end{array}$ & $\begin{array}{c}\text { Total } \\
\text { No. }(\%)\end{array}$ \\
\hline \multicolumn{4}{|c|}{ Number of HIV/AIDS patients seen in last 6 months } \\
\hline None & $16(22)$ & $59(57)$ & $75(42)$ \\
\hline $1-10$ & $40(54)$ & $11(11)$ & $51(29)$ \\
\hline $11-20$ & $7(09)$ & $1(01)$ & $8(04)$ \\
\hline $21+$ & $3(04)$ & $1(01)$ & $4(02)$ \\
\hline Don't know & $6(08)$ & $19(18)$ & $25(14)$ \\
\hline No response & $2(03)$ & $13(13)$ & $15(08)$ \\
\hline Total & 74 & 104 & 178 \\
\hline \multicolumn{4}{|c|}{ Number of HIV/AIDS patients seen in the last year } \\
\hline None & $12(16)$ & $53(51)$ & $65(37)$ \\
\hline $1-10$ & $33(45)$ & $16(15)$ & $49(28)$ \\
\hline $11-20$ & $11(15)$ & $3(03)$ & $14(08)$ \\
\hline $21+$ & $6(08)$ & $4(04)$ & $10(06)$ \\
\hline Don’t know & $6(08)$ & $18(17)$ & $24(13)$ \\
\hline No response & $6(08)$ & $10(10)$ & $16(09)$ \\
\hline Total & 74 & 104 & 178 \\
\hline \multicolumn{4}{|c|}{ Patient education on HIV/AIDS prevention } \\
\hline Yes & $62(84)$ & $86(83)$ & $148(83)$ \\
\hline No & $11(15)$ & $17(16)$ & $28(16)$ \\
\hline No response & $1(01)$ & $1(01)$ & $2(01)$ \\
\hline Total & 74 & 104 & 178 \\
\hline \multicolumn{4}{|c|}{ Reasons for not providing patient education on } \\
\hline \multicolumn{4}{|c|}{$\begin{array}{l}\text { (Texas = } 11 \text { respondents; Nuevo Leon = } \\
17 \text { respondents) }\end{array}$} \\
\hline Uncomfortable & 1 & 1 & 2 \\
\hline No time & 3 & 1 & 4 \\
\hline Other & 4 & 6 & 10 \\
\hline No reason given & 5 & 15 & 20 \\
\hline \multicolumn{4}{|c|}{$\begin{array}{l}\text { Usual medium for providing HIV/AIDS } \\
\text { prevention information }\end{array}$} \\
\hline Written & $10(14)$ & $11(11)$ & $21(12)$ \\
\hline Oral & $46(62)$ & $76(73)$ & $122(69)$ \\
\hline Referral & $5(07)$ & $0(00)$ & $5(03)$ \\
\hline No response/do not provide & $13(18)$ & $17(16)$ & $30(17)$ \\
\hline Total & 74 & 104 & 178 \\
\hline
\end{tabular}

6 months prior to being interviewed. Four respondents (one in Nuevo Leon and three in Texas) had seen more than $20 \mathrm{HIV} / \mathrm{AIDS}$ patients in that period. Ten clinicians had seen more than 20 patients with HIV/AIDS in the previous year (six in Texas, four in Nuevo Leon).

Interestingly, $8 \%$ of the clinicians in Texas and $17 \%$ of those in Nuevo Leon could not say whether or not they had seen an HIV patient in the previous year. Nevertheless, most survey respondents seemed to be aware of the threat that HIV presents to their patients. Over $80 \%$ in each setting provided HIV prevention education to patients whom they deemed to be at risk for infection. Among those who did not educate their patients in HIV prevention, a few said that doing so would make them feel uncomfortable or take too long, while most offered no reason. Among those who did provide HIV prevention information to their patients $(84 \%$ in Texas and $83 \%$ in Nuevo Leon), most did so orally.

When taken as a group, the clinicians in this study were either not seeing many HIV infected patients or were failing to recognize the condition. It was also surprising, given the epidemiology of AIDS in the two countries, that one-sixth of all physi- 
cians surveyed still did not incorporate HIV prevention messages into their practices.

\section{Knowledge with respect to HIV/AIDS}

The respondents were asked to rate their own knowledge of HIV/AIDS. Nearly $80 \%$ of those in Texas and over $90 \%$ of those in Nuevo Leon rated their knowledge as average or above average, as shown in Table 3. However, when asked to rate their knowledge of HIV/AIDS treatments and guidelines, nearly half from both areas (43\% in Texas and $48 \%$ in Nuevo Leon) rated themselves below average. As a test of specific knowledge of HIV/ AIDS, the Texas mail questionnaire asked whether respondents were familiar with ACTG 076, the clinical trial which showed that administration of zidovudine to HIV-infected pregnant women and their newborns can reduce HIV transmission from mother to fetus by two-thirds (8). Four out of 34 $(12 \%)$ indicated that they were familiar with the study. The same clinicians were also asked if they were familiar with Texas laws regarding HIV testing of pregnant women, and three $(9 \%)$ gave affirmative responses.

About $68 \%$ of physicians in Texas and $42 \%$ of those in Nuevo Leon said they relied on medical journals for their information about HIV/AIDS. An additional $4 \%$ of Texan clinicians and $29 \%$ of those from Nuevo Leon kept up with developments in the field of HIV/AIDS through attending conferences. Surprisingly, less than $5 \%$ of the respondents in either area attended university-based continuing education programs to obtain information about HIV infection.

\section{Attitudes and barriers against treating HIV/AIDS patients}

A substantial majority of respondents $(82 \%$ in Texas and $75 \%$ in Nuevo Leon) said that they were willing to see patients with HIV/AIDS, as seen in Table 4 . Conversely, however, $16 \%$ of

TABLE 3. Knowledge and sources of information regarding HIV/AIDS

\begin{tabular}{|c|c|c|c|}
\hline & $\begin{array}{l}\text { Texas } \\
\text { No. }(\%)\end{array}$ & $\begin{array}{l}\text { Nuevo Leon } \\
\text { No. (\%) }\end{array}$ & $\begin{array}{l}\text { Total } \\
\text { No. }(\%)\end{array}$ \\
\hline \multicolumn{4}{|c|}{ Self-assessment of general knowledge on HIV/AIDS } \\
\hline Below average & $14(19)$ & $7(07)$ & $21(12)$ \\
\hline Average & $45(61)$ & 76 (73) & $121(68)$ \\
\hline Above average & $15(20)$ & $21(20)$ & $36(20)$ \\
\hline Total & 74 & 104 & 178 \\
\hline \multicolumn{4}{|c|}{ Self-assessment of knowledge on HIV/AIDS treatment } \\
\hline Below average & $32(43)$ & $50(48)$ & $82(46)$ \\
\hline Average & $34(46)$ & $45(43)$ & 79 (44) \\
\hline Above average & $8(11)$ & $9(09)$ & $17(10)$ \\
\hline Total & 74 & 104 & 178 \\
\hline \multicolumn{4}{|c|}{ Familiarity with ACTG 076 clinical triala $^{a}$} \\
\hline Familiar & $04(12)$ & & \\
\hline Unfamiliar & $30(88)$ & & \\
\hline Total & 34 & & \\
\hline \multicolumn{4}{|c|}{$\begin{array}{l}\text { Familiarity with Texas state guidelines for HIV } \\
\text { testing in pregnancy }{ }^{\mathrm{a}}\end{array}$} \\
\hline Familiar & $3(09)$ & & \\
\hline Unfamiliar & $31(91)$ & & \\
\hline Total & 34 & & \\
\hline \multicolumn{4}{|c|}{ Most common source for HIV/AIDS information } \\
\hline Journal articles & $50(68)$ & $44(42)$ & $94(53)$ \\
\hline Continuing education & $3(04)$ & $5(05)$ & $8(04)$ \\
\hline Other conferences & $3(04)$ & $30(29)$ & $33(19)$ \\
\hline Other sources & $4(05)$ & $2(02)$ & $6(03)$ \\
\hline No response/none & $14(19)$ & $23(22)$ & $37(21)$ \\
\hline Total & 74 & 104 & 178 \\
\hline
\end{tabular}

a This question was only asked of Texas physicians responding to the mail questionnaire.

TABLE 4. Willingness to treat and barriers to treating HIV/AIDS patients

\begin{tabular}{lrrr}
\hline & $\begin{array}{c}\text { Texas } \\
\text { No. }(\%)\end{array}$ & $\begin{array}{c}\text { Nuevo Leon } \\
\text { No. (\%) }\end{array}$ & $\begin{array}{r}\text { Total } \\
\text { No. (\%) }\end{array}$ \\
\hline Respondents' willingness to treat HIV/AIDS patients & & & \\
Not willing & $12(16)$ & $25(24)$ & $37(21)$ \\
Somewhat willing & $24(32)$ & $41(39)$ & $65(37)$ \\
Very willing & $37(50)$ & $37(36)$ & $74(42)$ \\
No response & $1(01)$ & $1(01)$ & $2(01)$ \\
$\quad$ Total & 74 & 104 & 178 \\
Barriers to treating HIV/AIDS patients & & & \\
Fear of transmission & $11(15)$ & $25(24)$ & $36(20)$ \\
Treating homosexuals & $2(03)$ & $0(00)$ & $2(01)$ \\
Not trained enough & $10(14)$ & $22(21)$ & $32(18)$ \\
What other patients would say & $1(01)$ & $0(00)$ & $1(01)$ \\
What my co-workers would say & $1(01)$ & $0(00)$ & $1(01)$ \\
What my family would say & $2(03)$ & $0(00)$ & $2(01)$ \\
No barriers & $38(51)$ & $51(49)$ & $89(50)$ \\
No response & $9(12)$ & $6(06)$ & $15(08)$ \\
$\quad$ Total & 74 & 104 & 178 \\
\hline
\end{tabular}

clinicians from Texas and $24 \%$ of those from Nuevo Leon were unwilling to care for such patients.

Half of the physicians in both states (51\% in Texas and $49 \%$ in Nuevo Leon) denied experiencing any barriers to treating patients with HIV/AIDS. Fear of becoming personally infected was the barrier most often cited $(15 \%$ of clinicians from Texas and $24 \%$ of clini- 
TABLE 5. Opinions on Hispanics' needs with respect to HIV/AIDS

\begin{tabular}{|c|c|c|c|}
\hline & $\begin{array}{l}\text { Texas } \\
\text { No. }(\%)\end{array}$ & $\begin{array}{l}\text { Nuevo Leon } \\
\text { No. (\%) }\end{array}$ & $\begin{array}{l}\text { Total } \\
\text { No. }(\%)\end{array}$ \\
\hline \multicolumn{4}{|c|}{$\begin{array}{l}\text { Belief that Hispanics have special needs } \\
\text { regarding HIV/AIDS }\end{array}$} \\
\hline Yes & $57(77)$ & $83(80)$ & $140(79)$ \\
\hline No & $17(23)$ & $20(19)$ & $37(21)$ \\
\hline No response & $0(00)$ & $1(01)$ & $1(01)$ \\
\hline Total & 74 & 104 & 178 \\
\hline \multicolumn{4}{|c|}{$\begin{array}{l}\text { Nature of Hispanics' special needs with regard } \\
\text { to HIV/AIDS }\end{array}$} \\
\hline Sensitivity to culture & $47(64)$ & $38(37)$ & $85(48)$ \\
\hline Services need to be prov & & & \\
\hline Hispanic caregiver & $0(00)$ & $0(00)$ & $0(00)$ \\
\hline $\begin{array}{l}\text { Services need to be prov } \\
\text { community }\end{array}$ & $0(00)$ & $9(09)$ & $9(05)$ \\
\hline $\begin{array}{l}\text { Caregivers need to unde } \\
\text { attitudes on sex }\end{array}$ & $2(03)$ & $16(15)$ & $18(10)$ \\
\hline Diet & $1(01)$ & $06(06)$ & $7(04)$ \\
\hline No need or no response & $24(32)$ & $35(34)$ & $59(33)$ \\
\hline Total & 74 & 104 & 178 \\
\hline \multicolumn{4}{|c|}{$\begin{array}{l}\text { Willingness to attend training on psychosocial } \\
\text { aspects of HIV/AIDS }\end{array}$} \\
\hline Willing & $61(82)$ & $78(75)$ & $139(78)$ \\
\hline Unwilling & $12(16)$ & $25(24)$ & $37(21)$ \\
\hline No Response & $1(01)$ & $1(01)$ & $2(01)$ \\
\hline Total & 74 & 104 & 178 \\
\hline
\end{tabular}

cians from Nuevo Leon). Among physicians perceiving barriers, $14 \%$ of those in Texas and $21 \%$ of those in Mexico felt they lacked the skills to treat HIV infected patients.

\section{Special needs of Hispanic patients}

The vast majority $(79 \%)$ of the respondents felt Hispanic patients with HIV/AIDS have special needs, but Texan and Mexican physicians construed these needs differently. As shown in Table 5, 64\% percent of Texan clinicians but only $37 \%$ of Mexican clinicians reported feeling that the most important special need was to be sensitive to Hispanic culture and traditions. The difference seems to reflect the fact that HIV/AIDS patients in Nuevo Leon are already being cared for within their own cultural setting. The need for cultural sensitivity is more strongly felt in Texas, where Hispanic culture and customs are not dominant. A large proportion of the re- spondents in both states $(82 \%$ in Texas and $75 \%$ in Nuevo Leon) said they were willing to attend training on the psychosocial aspects of HIV/AIDS.

\section{Effect of age on clinicians' responses}

Most clinicians in this study received their primary medical education prior to the recognition of AIDS in the early eighties. Therefore, clinicians over 40 years of age were compared with those under 40 to determine if their differing exposures to HIV/AIDS during their years of formal education might have resulted in differences in self-assessed knowledge about the disease. No important differences were found. (Data not shown.)

\section{DISCUSSION}

This study was not a random survey, and its results should not be ex- trapolated to all clinicians in the border area. However, the respondents hail from a broad range of specialties and types of practices. Their responses provide suggestive insights into the level of HIV/AIDS-related knowledge among physicians in Texas and in Nuevo Leon.

The survey results revealed a serious lack of knowledge about HIV/ AIDS among a substantial proportion of respondents. They also showed that the majority of a group of actively practicing, mainly primary care physicians considered themselves as having below average knowledge about HIV/ AIDS treatment and guidelines. The Texas clinicians were unfamiliar with the study that showed how to prevent transmission of HIV from mother to child during pregnancy. One-sixth of all survey respondents failed to include patient education on HIV prevention in their practices, despite the fact that a majority of Texan clinicians and nearly one-fourth of those from Nuevo Leon had seen at least one HIV/AIDS patient in the course of the previous year.

The findings reported in this study are troubling. First, physicians acknowledged having little knowledge and omitting patient education about HIV prevention at a time when the AIDS epidemic is escalating in the border area. Second, recently trained clinicians did not report feeling more knowledgeable about HIV/AIDS than their older colleagues. Third, nearly one-quarter of the respondents from Nuevo Leon and one-sixth of respondents from Texas regarded their personal risk of HIV infection as an important barrier to providing care to HIV/AIDS patients. Policymakers should take note of these findings, which strongly suggest that Hispanic patients in Texas and Nuevo Leon are not receiving optimal and culturallysensitive clinical care.

Clearly, there is a need for a major educational program aimed at physicians in both Texas and Nuevo Leon. It is also evident that university-based continuing education programs have been minimally effective to date. Different educational mechanisms are 
necessary. Mexican physicians have expressed a preference for on-site educational programs, a strategy that could be fruitfully extended to Texas clinicians. Trans-border educational initiatives based on reciprocity should also be explored. Texas clinicians could share their broader clinical experience of HIV/AIDS with their Mex- ican colleagues. In turn, Mexican clinicians could provide their Texas colleagues with a deeper understanding of Mexican culture as is relevant to the treatment and support of Hispanic patients with HIV/AIDS. The problem of HIV/AIDS does not stop at the border, and neither should clinician education.
Acknowledgments. This study was supported in part by the HIV/AIDS Bureau (HAB), Health Resources and Services Administration (HRSA), U.S. Public Health Service, under cooperative agreement \#2U69PE00116-06. All representations are the sole responsibility of the authors and not of the HAB or HRSA.

\section{REFERENCES}

1. Centers for Disease Control and Prevention. HIV/AIDS Surv Rep 1996;8(1):5

2. Valdespino-Gómez JL, García-García ML, Del Río-Zolezzi A, Magis-Rodríguez C. El SIDA en México. Salud Publica Mex 1995;37:556-571.

3. Consejo Nacional de Prevención y Control del SIDA (CONASIDA). Epidemiología del SIDA/VIH en México de 1983 a octubre de 1996. http://148.247.112/conasida/index.html

4. Centers for Disease Control and Prevention. HIV/AIDS Surv Rep 1991;3(1):7.

5. Texas Department of Health, HIV/STD Epidemiology Division, Surveillance Branch. Texas
AIDS surveillance report, April-June 1996. Austin: Texas Department of Health; 1996.

6. United States Department of Commerce, Bureau of the Census. 1990 Census of population, general population characteristics of the State of Texas. Washington, D.C.: USDC; 1992.

7. Selwyn BJ, Loe HD, Moore FI. I, The Valley primary health care review: A report by the Indigent Health Care Review Committee of the Health Planning Advisory Committee of the Lower Rio Grande Valley Development Council. Houston: University of Texas School of Public Health Research Council; 1989.
8. Connor EM, Sperling RS, Gelber R, Kiselev P, Scott G, O'Sullivan MJ. Reduction of maternalinfant transmission of human immunodeficiency virus type 1 with zidovudine treatment. New Engl J Med 1994;331:1173-1180.

Manuscript received on 26 February 1997. Revised version accepted for publication on 22 January 1998.
RESUMEN

Prácticas, conocimientos y necesidades educativas sobre $\mathrm{VIH} /$ sida de los médicos hispanos en Texas, Estados Unidos, y Nuevo León, México
Los médicos hispanos que ejercen en Texas, Estados Unidos de América, y en el estado vecino de Nuevo León, México, fueron encuestados para determinar si necesitaban recibir capacitación en materia de $\mathrm{VIH} /$ sida. Dos terceras partes de los 74 médicos interrogados en Texas y 22\% de los 104 interrogados en Nuevo León habían examinado como mínimo a un paciente de VIH/sida durante el año previo. La mayoría de los encuestados eran médicos de atención primaria que 1) ejercían su profesión en lo privado; 2) veían a más de 1000 pacientes al año; 3) habían terminado sus estudios hacía más de 10 años; 4) proporcionaban educación preventiva a sus pacientes según la impresión que tuvieran del riesgo de cada uno; 5) dijeron poseer conocimientos normales sobre $\mathrm{VIH} /$ sida, pero inferiores a lo normal en lo referente a su tratamiento; 6) sacaban la mayor parte de su información sobre VIH/sida de revistas, y no de programas de educación continuada; 7) opinaban que los pacientes hispanos tenían necesidades especiales en torno a VIH/sida, y 8) estaban dispuestos a asistir a programas educativos para mejorar su habilidad en el manejo de pacientes con $\mathrm{VIH} /$ sida. Los factores que más obstaculizaban la atención de los pacientes con infección por VIH fueron la falta de conocimientos sobre los aspectos clínicos de la enfermedad y el temor a infectarse. Estos resultados apuntan hacia la necesidad de establecer un programa de adiestramiento a gran escala para mejorar la habilidad de los médicos hispanos en Texas y Nuevo León para tratar a pacientes con VIH/sida. 